\title{
The Recent History Teaching in the Political Function of Education: The Macro Public Policies on Memory and the Construction of Citizenship
}

\author{
Carla Bernardoni \\ Uruguayan State University \\ National Public Education Administration
}

The relationship between the recent public policies on memory linked to the dictatorships from 1960 to 1980 in the Southern Cone and the disciplinary curricular renewal of History curricula and programs in Uruguay, inspired this article. The controversial contents of the recent past and the violation of human rights, responsibility of the dictatorial State (1973-1984) were discussed in the classroom. The analysis of these episodes showed challenges and difficulties for the teachers and the educational system. From resistance to address the recent past for fear of confronting the families' versions or violating secularism, to defiant strategies, their approach revealed a still traumatic past for Uruguayan society. To examine how it was taught in 3rd year high school history, qualitative research was used, based on "the case study". Classroom observation, analysis of the teacher's documentation and interviews with three teachers revealed that they accepted the challenge, selecting and developing a variety of strategies, incorporating family testimonies, promoting debate and reflection and emphasizing both on the construction of critical citizenship and on local history.

Keywords: teaching of recent history, human rights, teaching strategies

\section{INTRODUCTION}

In the first years of the Uruguayan democratic recovery, the Education authorities expressed the importance of including Recent History in the teaching plans. This initiative faced objections from some political leaders and educational hierarchs; the existence of witnesses and conflicting memories within society made its implementation more complex and is still the subject of controversy. The media interfered in the teaching, demonstrating the difficulties in the incorporation of these new contents. Those who challenged the teaching of history close to the subject who lives it, argued that it was "biased" and recommended avoiding "sensitive topics" that could violate secularism, in what should be a "politically neutral teaching" (Demasi, 2010, p.50).

The investigation of this part of the teaching of history involved a challenge in a double sense. First, because it allowed us to learn about educational practices that are generally hidden and outside the "control of the authorities", which, according to historian Carlos Demasi (2010), implies questioning "a whole structure of hegemonic thinking, still in force in Uruguay" (p. 52). The second reason is that in the teaching of history there was room for a plurality of voices that questioned the conception of history as the provider of a "single truth". 
At the same time, its inclusion was framed in a political scenario of institutional changes in the State and in its relationship with society and formal education, during the expansion of a "culture of memory", linked to the commemoration and evocation of traumatic political processes and situations of repressive violence in the Latin American Southern Cone. Based on these foundations, the debates on the memory of violent periods are considered as an expression of the need to build democratic societies, in which the aims of education are focused on satisfying the aspirations of society as a whole and not those of groups in power.

Consequently, the memory space is a space of struggle, of confrontation, which was transferred to the classroom and educational institutions. History teachers faced in their classes a paradigm shift that placed them as the main protagonists and responsible for proposing a renewal of their strategies, between the "supposed" objectivity of historical research and the memory's subjectivity.

Thus, the general purpose of this study is:

- To analyze the strategies adopted by teachers for the teaching of the Recent Past and their link with the public policies on memory.

Specific objectives

- To relay activities carried out in the high school classrooms.

- To investigate the political function of education in order to know how knowledge was developed and circulated in the classroom and the teacher's role in this configuration.

This topic was chosen for generational and professional reasons. From a collective memory influenced by events linked to the last dictatorship in Uruguay, fears and silences shaped a subjectivity marked by the representations of the past in a singular territory of the country's interior. Secondly, it makes sense within the educational policies established in the document "Education for all: a matter of human rights", which emerged from the 2nd EFA/PRELAC ${ }^{1}$ meeting, in 2007, in Buenos Aires. It establishes the link between

quality education and the teaching of Recent History, in order to contribute to greater social integration and the strengthening of democratic values. Respect for human rights and appreciation of diversity and dignity are its cornerstones.

Education, understood and exercised as a fundamental human right, contributes to the exercise of other rights: to participation, to the exercise of responsible and critical citizenship, without exclusion, and allows for increased productivity.

Recent history, also called "immediate history", "history of the present time", "current history", with theoretical and methodological differences, deals with the last part of "contemporary history". Professor José Pedro Barrán (2008) stated that the role of witnesses and the need to adhere to documentation "because the confrontation with society is permanent and rigorous" (p. 13). Therefore, it brings the student closer to the truth under development and promotes critical thinking.

The Italian historian Enzo Traverso (2006) mentioned the points that reveal its specificity: its relationship with time, crossed by the experiences of the subjects who study it and make its approach more complex.

"It is the history that can be produced regarding a time that was lived, which puts into discussion the historian's subjectivity, implies a more complex use of the sources and, obviously, opens the tangled problem of the relationship between history and memory. It is about making history from a process that is engraved in our individual and collective memory"2.

For all these reasons, the teaching of this part of history is more complex than others; it implies assuming the existence of conflicting memories in the classroom and outside of it. This challenges teachers to question students about their existence, to stimulate reflection and critical thinking in order to develop essential skills in the configuration of new citizenship for life in post-dictatorial democracies.

Historians Marchesi, Markarian and Yaffé (2016) studied the manifestations of the gradual deterioration of key aspects of coexistence in democracy in Uruguay between 1968 and 1973. In June 1973, "the period of the greatest state repression and violence in Uruguayan history began, reaching the extremes of state terrorism and even showing, at times, totalitarian pretensions" (p. 21). As a consequence, the 
recovery of democracy shows difficulties for its consolidation in the present; it is a past-present, a cycle that has not yet closed.

After some time had passed between that violent past and the present, the interest in investigating "Recent History" began to take up important places in cultural and political debates. The emergence of diverse histories, lived and suffered by societies under State terrorism, constitutes part of the unavoidable topics of the political and cultural agenda, in a time characterized by the tension of struggles for the past and possible future projects. In the Uruguayan case, the information provided by new research on the dictatorial period, academic, literary and journalistic studies, the construction of memorials and "marks of memories", as well as the commemoration of events associated with the period, express the need to transmit/teach these past experiences in order to provide information to the new generations who did not witness these events and avoid the repetition of these painful episodes.

In this context, some time after the democratic restoration, new public policies on memory, encouraged by the strong demands of society as a whole and in a regional context, were promoted in Uruguay. More than a decade after the restoration of democracy, a resolution of the Presidency of the Republic created the Commission for Peace - COMIPAZ in $2000^{3}$, marking a milestone in the official recognition of human rights violations during the dictatorship. This initiative made it possible to collect documents and testimonies but faced criticism and divisions in society. The "Final Report" presented to the President of the Republic acknowledged the existence of missing people in Uruguay and recommended that "an objective and global analysis of the sad reality experienced by the country should be promoted and encouraged at all levels, with special emphasis on curricula in general and in the training of teachers and educators in particular..."

The rise of the left party to government in Uruguay in 2005 implied a new commitment of the State with the recent past and with the promotion of policies to investigate that period. For the first time a government of the Republic entrusted an investigation to teams of researchers, archaeologists and historians from the University of the Republic to provide knowledge about crimes committed by the same State under a dictatorial regime. Within this framework, the Convention on

"Human Rights and Detained-Disappeared Persons" was signed in May 2005. The presentation of the "Historical Research on Detained and Disappeared Persons" (2007) allowed the reconstruction of the repressive contexts during the dictatorial regimes in the region and provided information for the knowledge of the families of the victims as well as for academic researchers and society. As of 2010, research updates are available on the Presidency's website ${ }^{6}$.

Subsequently, the creation of the "Secretariat for Human Rights for the Recent Past" (SDDHHPR) in cooperation with the Ministry of Interior (2013) and the "Working Group for Truth and Justice" sought to expand investigations of crimes against mankind committed by State agents within or across borders between 1968-1973. The authorization by law (No. 18596, 2009) to grant economic, moral or symbolic compensations to the victims of State Terrorism; as well as the installation of an Interministerial Commission to oversee compliance with the judgment of the Inter-American Court of Human Rights in 2011, sought to deepen the policies related to human rights violations during the dictatorship.

This emphasis on public policies on memory "make visible and investigate episodes that took place during the last dictatorship" (Sosa, 2014, p.14) respond to the demands of collectives (grouped by sectors or individually), seek to affirm the rights of citizenship and strengthen democracy as a regime in the present and in the future in the country.

The implementation of new public policies on memory had impacts within the educational system and inserted the reformulation of the curriculum with new History contents in High School.

On October 25, 2005, the Central Board Council ${ }^{7}$ of the National Administration of Public Education ${ }^{8}$ resolved to entrust the different Elementary, High School, Technical-Professional and Teacher Training Councils with the task of adapting their programs to address the Recent History of Uruguay and the region. The selection of candidates who offered courses for teachers and materials for their study and dissemination, broadcast on open television, generated a strong debate and this polarization was reflected in the media. The objectivity "ghost" in the story and suspicions about the new versions reappeared. 
In this regard, in the publication "Recent History, history under discussion", historian Ana Frega (2008) recognizes the initiatives undertaken by ANEP to adapt the History programs of the second half of the 20th century and the courses for teachers, efforts that have been undermined by various arguments. For some, because of the proximity of the elapsed time, which prevents an "objective vision" and for others, because it is necessary to think about the future of the country and not the past. This position promotes a straightforward interpretation of the confrontation between two antagonistic forces: "the two demons", which omits the complexity and disregards the "structural and conjunctural aspects of local, regional and international nature that defined the period" (p. 16). The researcher also points out the heterogeneity of the available materials and the need for teachers and professors to make critical use of them.

In order to contribute emphasizing the importance of the teaching, Frega (2008), includes another focus of analysis. According to her, the increase in the demand from different social sectors to deepen their knowledge of the Recent Past favored the interest in learning about other processes and broadened the vision of topics that transcended the scope of national histories. The advancement of reflection on human rights and the deepening of democracy is linked to the analysis of other processes of social discrimination that involve new revisions of "forgotten" groups and incorporate "new historical subjects (workers, women, immigrants, etc.)" (p.28). The function of History is to give them visibility; addressing the conflicts that emanate from the plurality of views that have space for their expression in a state of law. The challenge for historians and teachers is to contribute towards the achievement of critical and reflective learning in order to be active citizens of their present and future.

In this confrontation context, in 2009, the General Assembly approved the General Education Law No. $18.437^{10}$, whose first article declares the promotion of the enjoyment and effective exercise of the right to education as a fundamental human right to be of general interest. The State shall guarantee the promotion of quality education for all its inhabitants throughout their lives, facilitating educational continuity. In her articles, she records the enjoyment and exercise of the right to education as a public and social good whose purpose is the full development of all people, without any discrimination whatsoever.

Education shall be focused on the search for a harmonious and integrated life through work, culture, entertainment, health care, respect for the environment, and the responsible exercise of citizenship, as essential factors for sustainable development, tolerance, the full exercise of human rights, peace and understanding among peoples and nations. The General Education Law declares that education shall have the human rights recognized in the Universal Declaration of Human Rights, in the Constitution of the Republic and in all international instruments adopted in the country, as essential elements incorporated into educational proposals, programs and actions.

All of the above shows the State's intention to promote and generate democratic values in young people through education, by disapproving of dictatorial forms of government and human rights violations. These initiatives, which are integrated in complex democratization processes, still raise discussions about their content and deepening. A starting point is proposed by Jelin (2002) when proposing that the debates about the memories of periods of political violence should be oriented to "build democratic orders in which human rights are guaranteed for the entire population" (p. 11). From a pedagogical point of view, analyzing the Recent Past is aimed at offering rigorous explanations to encourage reflection and the transmission of the importance of democracy in the classroom.

Educational institutions are the stages in which this innovation is deployed, places that summon teenagers every day and open themselves to their expectations in order to learn the meaning of collective life. These institutions acquire prominence in times of deep changes in family and social relations. Hence, the relevant task of teachers, called "parental guidance providers" by psychologist Dr. Carmen Rodriguez ${ }^{11}$. These adults, educators, models show the learners other ways of being adults, other ways of understanding the world and the meaning of living.

What do teachers do to promote the interaction with "others"? The convergence of interests and cultures continues attracting teenagers. Meanwhile, do the teachers listen to their expectations of civic life; do they encourage the construction of their links and knowledge in a climate favorable to debate? Do they promote participation and respect for human rights? Therefore, the question is whether there are still signs of 
authoritarianism in educational practices or whether the rights of learners are contemplated and, consequently, classroom spaces are places where life in democracy is exercised.

\section{Materials and Methods}

For all of the above, addressing this complexity and seeking to understand the phenomena in the classrooms is what we wanted to observe in the fieldwork.

The selection of a qualitative methodology to investigate how History teachers approach the stage known as Recent History entailed the observation of classes of three teachers -who will be named with the letters A, B and C-, in High Schools $\mathrm{N}^{\circ} 1$ and 7 of the city of Paysandú. The time period was between September and October 2017. In this way, the goal was to make visible the silenced aspects of classroom work, as well as the organization and implementation of activities related to the content in question.

To this end, the research explored the approach to the period that began with the crisis of the 1960s, the 1973 coup d'état, the dictatorship and the transition to democracy; the way in which political and economic aspects and the lives of the different social actors were worked and transmitted in the classroom - taking as a case study the high schools in the department of Paysandú.

TABLE 1

\section{FIELD RESEARCH ORGANIZATION}

\begin{tabular}{|c|c|c|c|c|}
\hline $\begin{array}{l}\text { Problem } \\
\text { under } \\
\text { investigation }\end{array}$ & $\begin{array}{l}\text { Specific } \\
\text { objectives }\end{array}$ & $\begin{array}{l}\text { Questions } \\
\text { posed }\end{array}$ & $\begin{array}{l}\text { Resources to answer the } \\
\text { questions posed }\end{array}$ & $\begin{array}{l}\text { Techniques } \\
\text { used }\end{array}$ \\
\hline \multirow[t]{2}{*}{$\begin{array}{l}\text { How was the } \\
\text { implementation of } \\
\text { the Recent } \\
\text { History teaching } \\
\text { at the high school } \\
\text { level carried out? }\end{array}$} & $\begin{array}{l}\text { Analyze the } \\
\text { approach in } \\
\text { the classroom. }\end{array}$ & $\begin{array}{l}\text { What are the } \\
\text { strategies that } \\
\text { teachers select. }\end{array}$ & $\begin{array}{l}\text { To select teachers in the same } \\
\text { course to compare classroom } \\
\text { situations in the teaching of } \\
\text { the recent past. Description of } \\
\text { classroom situations studied } \\
\text { Documentation analysis. } \\
\text { Generation of analysis } \\
\text { categories. }\end{array}$ & $\begin{array}{l}\text { Observation } \\
\text { Interviews } \\
\text { Documentary } \\
\text { review. }\end{array}$ \\
\hline & $\begin{array}{l}\text { To select } \\
\text { strategies for } \\
\text { discussion } \\
\text { and } \\
\text { dissemination. }\end{array}$ & $\begin{array}{l}\text { What are the } \\
\text { teacher and } \\
\text { student } \\
\text { implications of } \\
\text { dealing with } \\
\text { the recent past. }\end{array}$ & $\begin{array}{l}\text { To identify strengths and } \\
\text { difficulties regarding the } \\
\text { treatment. To establish links } \\
\text { with public policies on } \\
\text { memory. }\end{array}$ & \\
\hline
\end{tabular}

Developed by the author.

Based on this analysis, the following categories of analysis were developed: the didactic strategies selected by teachers to learn how the recent past was taught in these classes and the relationship between these practices and the new public policies on memory in the country and the region.

The recording of classes, the information obtained from the teacher's documentation and the crosschecking with the in-depth interviews conducted with the teachers observed, complemented what was observed and analyzed in the classrooms. It also sought to understand the selection of such strategies, the difficulties, challenges and opportunities, in relation to the topic in question.

Based on a selection of sub-categories within the general strategies, the analysis focused on the description and interpretation of what was observed, making a three-way analysis with the material from the teachers and the interviews conducted after the classroom observations. For these reasons and in order to carry out this research, a classroom observation guideline was designed: 
- Presentation and development of the topic by the instructor

- Student participation

- Use of the resources selected by the teacher

- Evaluation

\begin{tabular}{|l|}
\hline Documentary analysis matrix \\
- Teachers' notebooks for these classes \\
- Annual plan analysis \\
- Student grades for the subject \\
- Reading of the course development
\end{tabular}

The observation was directed by the categorization of De la Torre $(2000)^{12}$. For this researcher, strategies are open procedures that are specified in practice; this undefined character entails a dose of ideology and political decision that reflects a conception of the discipline, its goals and the ways of understanding the learning process of students. They call for innovation in the use of resources and teaching strategies to make this knowledge meaningful, integrated and transferable.

According to Cecilia Bixio ${ }^{13}$ (2005), didactic strategies represent the set of actions carried out by the teacher with a pedagogical intentionality. She considers the exchange among teachers to be fundamental for motivating and adapting their practices to the demands of the new times. The incorporation of innovative and creative strategies should be a driving force for change, exchange and reflection among teachers engaged in the education quality and the evolution of their role in democratic societies.

TABLE 2

\section{CLASSROOM STRATEGIES}

\begin{tabular}{|l|}
\hline 1. Strategy: search for the documentary source \\
2. Interrogation strategy \\
3. Error correction strategy \\
4. Interviews \\
5. Research Strategy \\
6. Family consultation \\
7. Use of audiovisual resources \\
8. Oral presentation strategy \\
9. Testimonial search \\
10. Elaboration of conceptual tables. \\
11. Teaching by discovery \\
12. Diachrony and synchrony \\
\hline
\end{tabular}

After the observation, the research was followed by interviews with teachers in order to understand the selection of content and resources. These sources were integrated and triangulated with the observation and documentation made available to the author. The interviews were semi-structured, addressed to the teachers observed; students were not interviewed. The following are the questions asked:

- Is the recent past of the transmitting subject's time teachable?

- Have you perceived changes in relation to your teaching in the country? Which ones?

- What teaching strategies and resources do you select for teaching Recent History in the classroom?

- How does the student learn about the dictatorship in relation to the information/communication he/she received in other spaces? 


\section{RESULTS}

The analysis of the identified practices confirmed that teachers have followed the guidelines of educational policies to undertake their teaching, to enable discussion and awareness of the subject's role in the historical development. To this end, they deployed a combination of strategies; it is not possible to refer to the use of a single pure strategy, in an essentialist sense; some were more innovative and creative, others more traditional but equally effective. Without claiming to evaluate the use of strategies by all teachers working with this program, the analysis focused on the actions of the three teachers surveyed, together with the work material made available to the author.

This selection made transparent the decisions and rankings made by the history teachers in their classes. Therefore, by analyzing the way they organized the content and the way they taught it, they revealed aspects of their teaching styles and their conception of History. When the teachers were questioned about this selection and its epistemological foundations, they showed aspects of their own biographies.

The focus of the work was on what was considered the most significant teaching practices in History in the classrooms visited; to this end, we opted to investigate those that were the most creative and effective in terms of results and student involvement. In some cases these were shared among the teachers and in others it was the original approach of a teacher by virtue of her objectives and not of the group in which it was proposed. An additional focus of analysis was the way in which the different proposals were carried out, whether there were clear guidelines, co-established between the teacher and the students, and what degree of receptivity they had when they were put forward. Next, the results obtained in the students' work (whether group or individual) and how these results were integrated into the evaluation processes.

TABLE 3

GROUPS, PERIODS AND STRATEGIES STUDIED

\begin{tabular}{|c|c|c|c|c|c|c|c|}
\hline $\begin{array}{c}\text { Teaching } \\
\text { Group }\end{array}$ & $\begin{array}{c}\text { Time } \\
\text { Number of } \\
\text { classes }\end{array}$ & $\begin{array}{c}\text { Oral } \\
\text { presentation } \\
\text { strategy }\end{array}$ & $\begin{array}{c}\text { Interrogation } \\
\text { strategy }\end{array}$ & $\begin{array}{c}\text { Testimonial } \\
\text { search } \\
\text { strategy }\end{array}$ & $\begin{array}{c}\text { Strategy } \\
\text { for working } \\
\text { with } \\
\text { documents }\end{array}$ & $\begin{array}{c}\text { Research } \\
\text { Work }\end{array}$ & $\begin{array}{c}\text { Strategy for } \\
\text { working } \\
\text { with } \\
\text { audiovisual } \\
\text { resources }\end{array}$ \\
\hline $\begin{array}{c}\text { Lic. 7 } \\
\text { Doc. A }\end{array}$ & Set. & $\checkmark$ & $\checkmark$ & $\checkmark$ & $\checkmark$ & & $\checkmark$ \\
\hline $\begin{array}{c}\text { Lic. 1 } \\
\text { Doc. B }\end{array}$ & $\begin{array}{c}\text { Set- Oct } \\
\text { modules }\end{array}$ & $\checkmark$ & $\checkmark$ & $\checkmark$ & $\checkmark$ & $\checkmark$ & $\checkmark$ \\
\hline Lic.1 & $\begin{array}{c}5 \\
\text { oct. 3 } \\
\text { Dodules. C }\end{array}$ & $\checkmark$ & & & & & \\
\hline
\end{tabular}

Developed by the author.

Once the observation phase was completed, the analysis of the strategies followed this order: 
1. Oral presentation, contextualization and interrogation.

2. Use of audiovisual resources, documents and bibliography.

3. Performance of interviews, search for testimonies and use of documents.

4. A research.

The analysis followed the classification of De la Torre and Barrios (2000) and Carretero, Pozo and Asensio (1991). The selection followed the criterion from less to more complex, focusing on the results obtained in the classroom. Subsequently, this information was complemented with the documentation provided by the teachers and the interviews.

First, the strategies of interrogation and oral presentations were the most developed in different moments of the class. Regarding the oral presentation, the teachers agreed on its effectiveness in introducing a topic, its contextualization and continuity. The questions selected explored the students' knowledge, from the weakest to others of greater argumentative consistency; the influx of answers and new questions, some with successes and others with mistakes, were favorable occasions for conceptual revision or the teacher's collective search for correction. They also emphasized the need to locate the contexts in which these events occurred and to observe the changes and permanence in the historical evolution.

In the second place, the State's support for research on the Recent Past encouraged the production of bibliographic, audio-visual and artistic material on the years prior to the dictatorship, its development and stages, and the democratic recovery. These devices had an important impact on the educational system in general and in particular in the high school and are currently available to students for study, all of which favored the incorporation of the topics of the current analysis. Regarding the selection of activities and resources, teacher A referred to the students' preference for this topic and their curiosity about the study of the dictatorship, generally unknown to them.

Through the use of available resources, the study of Recent History provided an entry into lived history. The display of documentaries, photos or listening to songs in class could be contrasted with family testimonies. In this way, the classroom enabled new knowledge forms, more experiential, giving the classes a dynamic and vitality that other History subjects do not have. When referring to the violence of the ' 60 s, the permanent violations of Human Rights, the questioning of the weakened democracy and the repression on the road to authoritarianism was visible.

Third, a recurring strategy frequently observed in the classes consisted of appealing to the memory of the families. Similar to teacher B, teacher C agreed with the students to conduct interviews with family members, neighbors or friends in order to collect testimonies about the origins of the dictatorship. The inquiry would allow us to know how they had lived and to ask questions, agreed upon with the students. The agreement between the teachers observed regarding the requirement of framing the testimonies and the information collected in a theoretical framework based on research, reveals the accuracy of the treatment of this period, establishing a clear differentiation between history and memory.

In the interview carried out with teacher $\mathrm{C}$, she emphasized that the strategy of building knowledge on the part of the students has given her excellent results and showed caution regarding the use of student testimonies because they constitute only a glimpse, they are contributions from the memory of the families. The other teachers pointed out the value of family testimony and stated that in the present, it emerges more freely. The time that has elapsed has enabled this flow of memories; it could be said, in line with Pollak (2006), that now there are those who are willing to listen.

These brief comments served as an example to explain that the methodological option selected provided elements that strengthened the field instance, i.e. classroom observations. At the same time, they allowed for a more complex and better understanding of the teaching processes of Recent History and its implications.

In this sense, and following Barrán (2008), the existing distinction between the teaching of Recent History with other stages of History, "it is the one that reveals to the student and to the reader the researcher's work and always puts it under question" (p. 13). According to the historian, his study emphasizes the precarious nature of all knowledge and, consequently, nourishes the critical spirit.

For teacher C, Recent History contributes to the formation of reflective citizens, broadens their view of local or global events and processes in order to understand them and make decisions in accordance with 
their ideas. In a similar direction, Teacher B recommended paying attention to the speeches made by politicians in the " $60 \mathrm{~s}$ and " $70 \mathrm{~s}$ and learning to decode the messages involved in them in order to practice responsible citizenship.

Fourth, teacher B, when asked about the strategy she considered most appropriate for teaching of Recent History, answered that it was the organization of a research on the dictatorship period. Its direction was intended to allow students to study with a plurality of views and gave them freedom for the interpretation of actions, thus promoting their autonomy and critical thinking. As the students formulated the research questions, some more "sensitive" questions emerged: "Do you think the dictatorship could be repeated?"

Once the information from the interviews conducted by the students had been gathered, the teacher classified them by sectors that made it possible to visualize recurrences and divergences in order to draw conclusions collectively. The research linked the students with the protagonists of Recent History, from a closer point of view. The final evaluation included the presentation of the research carried out by the teams that created their own sources, to be later expanded with the available literature.

The information provided by the three teachers generally matched the students' lack of knowledge regarding the period of the dictatorship. For two of them, the teaching of Recent History has a singularity that the so-called "traditional History" does not have, particularly the existence of witnesses who can challenge the teaching work. On the other hand, for teacher $\mathrm{C}$, there is no difference between one and the other: the written document, the audio-visual if available, supports the teaching of any stage of history.

The analysis of the classes allowed us to find similarities between the selection of activities and the didactic proposals observed. While for one teacher the information is "given" and the search for bibliographic material is facilitated, for another teacher the work in groups, with autonomy to search for the material, is more stimulating. The formulation of challenging questions, the exploration supported by audiovisual resources, journalistic articles and documents, played an important role in the selection of the teachers.

In terms of teaching, a new perspective was also maintained; it is not possible to teach "everything", the conception of History with the pretension of the knowledge neutrality has no place in the universe of current educational institutions. The greater material availability, the existence of a program that supports or enables classroom work on these contents, did not prevent the reference to the need for "caution" regarding their treatment and the aspiration to achieve "objectivity". This is not possible, but it is not an obstacle to exercise the teaching role from a critical distance.

The teachers under observation agreed that they had lived through the dictatorship, which influenced their education, both as citizens and as teachers. The political role of teaching in a democratic state was the subject of the research. The teachers agreed on their interest in the education of citizens. For one of them, from a perspective of politics in the details of her daily life, and for the others, in the contrast between life under dictatorship and human rights in democracy.

\section{DISCUSSION}

Once the research has been completed, it is possible to give an account of some of the paths followed, without the pretension of closing them, but rather of making them available for new incorporations. From this perspective, we witnessed the revelation of a plot that was born in the State, in times of political and social changes in a regional key. This was expanded to the students' families or close friends, who shared their experiences and enriched the views of the processes studied in the classrooms of the public institutions. There "all voices" were heard and confirmed that the imposed silence did not lead to oblivion, as Pollak (2006) stated:

... it is the resistance that a powerless civil society puts up to the excess of official speeches. At the same time, this society carefully transfers dissident memories in family and friendship networks, waiting for the moment of truth and the redistribution of political and ideological cards (p. 20). 
Following the implementation of new public policies on memory, the State supported the inclusion of Recent History and broadened the perspectives of its exploration. Based on a more flexible educational concept, adapted to different social contexts in freer and more open environments, teachers felt confident and supported in their performance, which led to greater guarantees for the learning of future citizens. The knowledge of the period in question achieved greater integration and strengthened the values of a democratic regime.

The research showed that macro educational policies are not by themselves generators of change, but require the commitment of those who carry them out. In this case, the key role of the teachers, leading a process within the classroom, linked those macro policies with micro stories in which the discussion had a significant weight. Following Barrán (2008) "the confrontation with society is permanent and rigorous" (p. 13). The contribution of the witnesses provided a more experiential structure anchored to the territory and challenged the students to appreciate the freedom they enjoy, the right to know by having a diversity of resources and study materials on the dictatorship period.

And here we find another key idea that emerged from the observation: the teaching of history was conceived as a transforming action, which had an effect on the learners. The changes in behavior resulting from the understanding of Recent History, the greater sensitivity to social issues or the participation in collective activities linked to memory are some demonstrations of a new positioning of the subject of politics.

Likewise, this plot emerged under the protection of the public policies on memory that supported the investigation of the dictatorship and the democratic recovery, and was deployed in the field of public high school education. These institutions have not been immune to the changes of current times; their functions have been redefined to offer an inclusive education that tends to a more integrated society, with equity, in which ideological plurality has expression and where all share the common.

The political function of education in the framework of democratic societies is unthinkable without its existence. These spaces are meeting places and places for the formation of subjectivities, places that provide psychological support and are the recipients of a number of subjects of rights, treated and integrated as "equals". In these classrooms, students took the floor, discussed proposals, addressed their research and their contributions were listened to and debated.

The emphasis placed on the losses of citizens living under dictatorship: the suspension of the Constitution and the submission to military justice, sought to alert students to the risks run when politics gives way to other forces.

The implementation of these political topics induced students to reflect on the importance of life, the vulnerability of people in a globalized world, connected or manipulated from the "outside". Among these tensions are the changes in the demands of the younger generations; the consumption demands; the sense of belonging to an elusive citizenship that alters identity, often linked to the possession of objects and not to the valuation of the subject.

\section{ACKNOWLEDGEMENT}

Translated \& edited by American Publishing Services (https://americanpublishingservices.com/).

\section{ENDNOTES}

1. Education for all. Regional Education Project for Latin America and the Caribbean.

2. Retrieved from: http://www.scielo.org.mx/scielo.php?script=sci_arttext\&pid=S1870-00632008000100010

3. Resolution of the Presidency of the Republic No. 858/2000, dated August 9, 2000.

4. Eastern Republic of Uruguay, Presidency of the Republic, 2003.

5. Retrieved from: http://www.fhuce.edu.uy/index.php/Institucional/ddhh-sociedad/pasado-reciente file://C:/ Users/ Usuario/ Documents/Maestr\%C3\%ADa\%20CFE-Flacso/Convenio\%20Presidencia-.\%20Udelar.pdf

6. In: sdh.gub.uy

7. Hereinafter CODICEN

8. Hereinafter ANEP 
9. In 2006, the publication "Recent History, history under discussion", under the direction of Álvaro Rico, brought together historians and other social scientists. Among them, Carlos Demasi, Ana Frega, Jaime Yaffé, Gerardo Caetano.

10. Law No. 18.437, on General Education, approved by the Executive Power on December 12, 2008.

11. Psychologist Dr. Carmen Rodríguez refers to "parental guidance providers" as those adults who take over the "baton" from parents and relatives during adolescence. Retrieved from: http://www.bibliotecaunicef.uy/ doc_num.php?explnum_id=127

12. Saturnino De la Torre, Spanish researcher.

13. Cecilia Bixio, professor and researcher at the Faculty of Psychology at the National University of Rosario (Argentina).

\section{REFERENCES}

Bohoslavsky, E., Franco, M., Iglesias, M., \& Lvovich, D. (compiladores). (2010). Problemas de historia reciente del Cono Sur. Buenos Aires, Prometeo, Libros.

Caetano, G. (comp). (2016). Uruguay. En busca del desarrollo entre el autoritarismo y la democracia (Tomo III. 1930/2010). Montevideo, Fundación MAPFRE.

Carretero, M., Pozo, J.I., \& Asensio, M. (comp). (1989). 1989 La enseñanza de las Ciencias Sociales. Madrid: Visor Distribuciones. Gráficas Rogar.

Convenio entre la Universidad de la República - Facultad de Humanidades y Ciencias de la Educación y Ministerio del Interior - Secretaría de Derechos Humanos. (2008). Retrieved December 21, 2017.

De la Torre, S., \& Barrios, O. (coords). (2000). Estrategias didácticas innovadoras. España: 2000, Ed. Octaedro, S.L.

Demasi, C. (2008). 2006: El año de la historia reciente. In A. Rico, Historia reciente, historia en construcción (pp. 31-32). Montevideo: Centro de Estudios Interdisciplinarios Uruguayos (CEIU). Facultad de Humanidades y Ciencias de la Educación, Udelar.

Educación para todos. (2007). Educación para todos: Un asunto de derechos humanos. Buenos Aires. II Reunión del Proyecto Regional de Educación para Latino América y el Caribe.

Frega, A. (2008). Combates por la "Historia reciente" en Uruguay. In A. Rico, Historia reciente, historia en construcción (pp.15-17). Montevideo: Centro de Estudios Interdisciplinarios Uruguayos (CEIU). Facultad de Humanidades y Ciencias de la Educación, Udelar.

Jelin, E. (2002). Los trabajos de la memoria. Madrid: Siglo veintiuno.

Pollak, M. (2006). Memoria, olvido, silencio. La producción social de identidades frente a situaciones limite. La Plata: Ediciones Al Margen.

Sosa, A. (2014). Entre la memoria y la historia: Políticas públicas en relación al pasado reciente en Brasil y Uruguay. Projeto História, 50, 11-45.

Stake, R.E. (2010). Investigación con estudio de casos. Madrid: Ediciones Morata, S.L.

Traverso, E. (2012). La historia como campo de batalla. Interpretar las violencias del siglo XX. Buenos Aires: Fondo de Cultura Económica. 